\section{Critically ill children did not benefit from tight glycaemic control}

\section{STUDY DESIGN}

Design: Randomised controlled trial.

Allocation: Computer generated block design.

\section{STUDY QUESTION}

Setting: Thirty-five paediatric intensive care unit (ICU) centres.

Patients: Three hundred and sixty patients (median age 5.5 years, IQR $1.4-12.5$ years) in the lower target group; 353 patients (median age 6.7 years, IQR $1.7-12.8$ years) in the higher target group.

Intervention: Randomisation to low target glycaemic control group $(80-110 \mathrm{mg} / \mathrm{dL}(3.3-6.1 \mathrm{mmol} / \mathrm{L}))$ or higher target glycaemic control group (150-180 mg/ dL (8.3-10 mmol/L).

Outcomes: Primary outcome: number of ICU-free days to day 28. Prespecified secondary outcomes: 90-day mortality, severity of organ dysfunction, the number of ventilator-free days to day 28 , incidence of healthcare-associated infection and incidence of hypoglycaemia.

Patient follow-up: Patient was followed up for 90 days. Recruitment stopped at 50\% due to low likelihood of benefit and potential of harm.
MAIN RESULTS

\begin{tabular}{|c|c|c|c|}
\hline Variable & $\begin{array}{l}\text { Low target } \\
(\mathrm{n}=349)\end{array}$ & $\begin{array}{l}\text { Higher target } \\
(n=349)\end{array}$ & $\mathrm{p}$ Value \\
\hline $\begin{array}{l}\text { Median (IQR), no of } \\
\text { ICU-free days through } \\
\text { day } 28\end{array}$ & $20(1-24)$ & $19.4(7.1-23.9)$ & 0.86 \\
\hline $\begin{array}{l}\text { 90-day hospital } \\
\text { mortality (\%) }\end{array}$ & $52(14.9)$ & $40(11.5)$ & 0.6 \\
\hline $\begin{array}{l}\text { Incidence of healthcare- } \\
\text { associated infection } \\
\text { (no/no of days with a } \\
\text { CVC/UTI/ventilator) }\end{array}$ & $12(3.4)$ & $4(1.1)$ & 0.04 \\
\hline $\begin{array}{l}\text { Catheter-associated } \\
\text { bloodstream infection }\end{array}$ & $5 / 2577$ & $0 / 2784$ & 0.03 \\
\hline Catheter-associated UTI & $5 / 2287$ & $4 / 2230$ & 1.0 \\
\hline $\begin{array}{l}\text { Ventilator-associated } \\
\text { pneumonia }\end{array}$ & $3 / 3182$ & $0 / 3371$ & 0.11 \\
\hline Hypoglycaemia (\%) & $79(22.8)$ & $33(9.5)$ & $<0.001$ \\
\hline
\end{tabular}

CVC, central venous catheter; UTI, urinary tract infection.

\section{CONCLUSION}

Maintaining tight glycaemic control (80-110 mg/ $\mathrm{dL}, 4.4-6.1 \mathrm{mmol} / \mathrm{L}$ ) for critically ill children with hyperglycaemia in paediatric ICU did not infer any benefit in terms of number of ICU-free days or mortality; severity of organ dysfunction or number of ventilator-free days. Infection rates were increased. Abstracted from Agus MSD, Wypji D, Hirshberg EL, et al. Tight glycaemic control in critically ill children. New Engl J Med 2017 [Epub ahead of print, 24 Jan 2017].
$\mathrm{T}$ he need to maintain tight glycaemic control in critically unwell patients has been a hot topic in intensive care medicine in recent years. One single-centre randomised controlled trial in adult surgical patients demonstrated a reduction in morbidity and mortality (van den Berghe et al, 2001), but this result was not shown consistently in other trials. It is known that there is a wide variation in practice in paediatric intensive care units; with the advent of continuous glucose monitoring it is now easier than ever before to track blood sugar readings and adjust insulin or fluid therapy as required. This study was therefore important and necessary in the effort to improve care and outcomes for critically ill children.

The study demonstrates that there was no benefit in the tight glycaemic control of critically ill children and that morbidity and 90-day mortality were increased in the low-target group. A rise in blood glucose is a normal physiological response to critical illness and a forced reduction in this may therefore do more harm than good. However, the increased risk secondary to the maintenance of tight glycaemic control may represent the administration of insulin therapy with its other metabolic effects as opposed to the absolute blood glucose levels.

The finding that there was an increase in healthcare-associated infections should be noted. Of course, this study was not powered to detect this effect and may reflect the sample size rather than a true finding.

In conclusion, this study shows that there is no clinical benefit for maintaining blood glucose control between 80 and $110 \mathrm{mg} / \mathrm{dL}$ (0.4-6.1 mmol/L) in critically unwell children. This is of relevance to any paediatricians caring for such children. Guideline development to standardise management for affected children would be useful.

\section{Angela Katrina Lucas-Herald, ${ }^{1}$ Kenneth J Robertson ${ }^{2}$}

'Developmental Endocrinology Research Group, University of Glasgow, Glasgow, UK

${ }^{2}$ Royal Hospital for Children, Glasgow, UK

Correspondence to Dr Angela Katrina Lucas-Herald, Developmental Endocrinology Research Group, University of Glasgow, 1345 Govan Road, Glasgow G51 4TF, UK; angela.lucas-herald@glasgow.ac.uk

Contributors AKL-H and KJR contributed equally to the preparation of the submitted manuscript.

Provenance and peer review Not commissioned; internally peer reviewed. C Article author(s) (or their employer(s) unless otherwise stated in the text of the article) 2017. All rights reserved. No commercial use is permitted unless otherwise expressly granted.

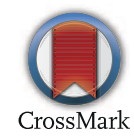

To cite Lucas-Herald AK, Robertson KJ Published Online First: [please include Day Month Year]. doi:10.1136/archdischild-2017-313012

Arch Dis Child Educ Pract Ed 2017;0:1.

doi:10.1136/archdischild-2017-313012 


\section{CDitically ill children did not benefit from tight glycaemic control}

Angela Katrina Lucas-Herald and Kenneth J Robertson

Arch Dis Child Educ Pract Ed published online May 23, 2017

Updated information and services can be found at:

http://ep.bmj.com/content/early/2017/05/22/archdischild-2017-313012

These include:

Open Access This is an Open Access article distributed in accordance with the terms of the Creative Commons Attribution (CC BY 4.0) license, which permits others to distribute, remix, adapt and build upon this work, for commercial use, provided the original work is properly cited. See:

http://creativecommons.org/licenses/by/4.0/

Email alerting Receive free email alerts when new articles cite this article. Sign up in the service box at the top right corner of the online article.

Topic Articles on similar topics can be found in the following collections

Collections

Open access (16)

\section{Notes}

To request permissions go to:

http://group.bmj.com/group/rights-licensing/permissions

To order reprints go to:

http://journals.bmj.com/cgi/reprintform

To subscribe to BMJ go to:

http://group.bmj.com/subscribe/ 